\title{
Ethnobotany and antibacterial potentiality of Blumea lacera L. from Sundarban Mangrove forest of Bangladesh
}

\author{
Fakhruddin Ali Ahmed*, Anisur Rahman, Sanzida Mubassara and \\ Gazi Mosharof Hossain \\ Department of Botany, Jahangirnagar University, Savar, Dhaka-1342, Bangladesh.
}

\begin{abstract}
Indigenous knowledge on the utilization of Blumea lacera L. by the interim people as well as ethnic communities living at the vicinity of Sundarban mangrove forest of Bangladesh were documented through survey, interview, collection and identification. Native people of Sundarban use the herb in bleeding piles. Leaf of the plant was found to be the most useful part for ethnomedicinal use. Generally, leaves of B. lacera have been used to treat most kinds of colds. Warm leaf paste used as diuretic whereas leaf paste with black pepper powder was found to apply in dog bite. Furthermore, B. lacera collected from Sundarban mangrove habitat as well as from natural plain land habitat (JU campus) were subjected to a comparative analysis of antibacterial activity. Antibacterial study from the present experiment suggested that the ethyl acetate fraction of $B$. lacera, irrespective of habitat choice, was active against the gram-positive bacteria Bacillus cereus. The methanol fraction of Sundarban sample showed significant dose dependent increase in antibacterial activity against the gram-negative bacteria Serratia sp., Proteus mirabilis, Salmonella typhi and Vibrio cholera while the JU sample did not produce any inhibition zone. The $n$-hexane fractions of both type plant samples were entirely non-responsive to the bacterial growth.
\end{abstract}

Key words: Ethnobotany, antibacterial activity, Blumea lacera, Sundarban mangrove forest.

\section{INTRODUCTION}

Primary tropical forest is generally considered to be the most likely habitat to discover new pharmaceuticals due to high biodiversity and endemism. However, many indigenous groups rely on forested and non-forested environments for medicinal plants. An ethnobotanical approach to drug discovery suggests that extreme environments may also harbor potentially useful medicinal compounds (Gentry, 1993; Macilwain, 1998). During the last ten years pace of development of new antimicrobial drugs has slowed down while the prevalence of resistance has increased astronomically (Akinpelu et al., 2009). According to WHO, medicinal plants would be the best source to obtain a variety of drugs. Systematic screening of folk medicines and plants may result in the discovery of novel effective compounds (Tomoko et al., 2002).

Blumea lacera L. belonging to the Asteraceae family is a common plain land weed of Bangladesh. This plant species also grows in Sundarban area and known as Kukursunga in that locality (Uddin et al., 2011). B. lacera has an enormous medicinal value and been widely used in the traditional medicinal system of Bangladesh for a long time. It is used

*Author to whom all correspondences should be made. E-mail: faahmed_ju@yahoo.com 
as antipyretic, stimulant, astringent, anthelmintic, febrifuge, diuretic and in hemorrhoids (Pandit et al., 1996) bronchitis (Jha \& Verma, 1996) as antimicrobial for healing cuts (Joshi, 1980) in urinary troubles (Singh, 1988) in irritation, as haemostatic (Kakrani \& Saluja, 1994) and anti-inflammatory (Pal, 1972). There are scanty reports on ethnobotany and antimicrobial activity of B. lacera that are found in mesophytic habitat (Tiwari et al., 2012; Singh et al., 2010) but yet now there is no aforesaid information of this plant grows in mangrove or halophytic habitat. Considering the above fact, present study was aimed to document the indigenous knowledge on the utilization of $B$. lacera by the ethnic communities living in the vicinity of Sundarban mangrove forest of Bangladesh followed by comparative analysis of antibacterial activity of the aerial parts of the plant collected from Sundarban as well as from Jahangirnagar University campus.

\section{MATERIALS AND METHODS}

Ethnobotanical study: The survey was conducted among the interim fisherman, forest guard, and honey collector of Kalagachia, Dublar Char and Kotka sites of Sundarban mangrove forest of Bangladesh. Data were collected in the field note book on the plant parts used, preparation of the drug, its dosage and administration etc. as given by the informants. Interviews were conducted with the help of a semi-structured questionnaire and the guided field-walk method of Martin (1995) and Maundu (1995). Interviews were conducted in the Bengali language. Notably, the Kavirajes practiced among the mainstream Bengali-speaking population.

Collection and Identification: Plant samples were collected from two different habitats namely Jahangirnagar University campus and Sundarban and were identified and authenticated by the Bangladesh National Herbarium (DACB), Mirpur, Dhaka, Bangladesh. The voucher specimens (accession no. of JU sample: DACB 38210 and Sundarbans sample: DACB 32624) have been deposited in DACB for further reference.

Preparation of crude extract and fraction: The collected aerial parts of both the samples were sun-dried followed by drying in a hot air oven (Gallenkamp) at reduced temperature $\left(<50^{\circ} \mathrm{C}\right)$. About $200 \mathrm{~g}$ powder was digested with $1000 \mathrm{ml}$ of ethanol for three days accompanying with occasional shaking and stirring. The whole mixtures was filtrated by a piece of clean, white cotton material. The extract was concentrated at $45^{\circ} \mathrm{C}$ under reduced pressure using a rotary evaporator.

Partition of the crude methanolic extract: Solvent-solvent partitioning was done by using the protocol designed by Kupchan \& Tsou (1973) and modified version of Wagenen et al. (1993). The crude ethanolic extract of the sample was first partitioned with $n$-hexane and methanol at ratio 1:1 using separating funnel and these two fractions were evaporated separately to dryness by rotary evaporator at $40^{\circ} \mathrm{C}$. Then the methanol fraction was further partitioned to ethyl acetate and methanol fractions and evaporated to dryness. Fraction samples were then marked and stored in dark, cold and dry place. 
Determination of antibacterial activity: Antibacterial potentiality of the fractions $(n$ hexane, ethyl acetate and methanol fractions) were determined by disc diffusion method following Saad et al. (2012). As per availability, two Gram positive bacteria Bacillus cereus and B. subtilis and eight Gram negative bacteria Erwinia sp., Proteus mirabilis, Pseudomonas sp., Salmonella sp., Salmonella typhi, Serratia sp., Shigella flexneri and Vibrio cholera were used to determine antibacterial activities. The sterile filter paper disc ( $8 \mathrm{~mm}$ diameter) containing three different concentration of the dry extracts $(40 \mu \mathrm{g} / \mathrm{ml}, 80$ $\mu \mathrm{g} / \mathrm{ml}$ and $120 \mu \mathrm{g} / \mathrm{ml})$, standard antibiotic disc $(5 \mu \mathrm{g} / \mathrm{ml}$ Streptomycine) and negative control (blank disc soaked with methanol solvent only) were used in the experiment and the results recoded as the mean values of three replications. The bacterial strains used for the experiment were collected as pure cultures from Microbiology laboratory, Department of Botany, Jahangirnagar University, Savar, Dhaka.

\section{RESULTS AND DISCUSSION}

Traditional medicinal practitioners tend to keep the treatment methods within the family, where the knowledge is passed on from generation to generation. As a result over the centuries, traditional medicine practitioners have developed a familiarity with plant species found in their region or habitat and the applicability of those plant species in treatment of various types of diseases. In the present study, interim peoples of the three sites namely Dublar char, Kalagachia and Kotka were surveyed to collect the information on medicinal use of $B$. lacera. About 25 people were asked to collect the information on B. lacera growing in Sundarbans. The plant was found non familiar to the local people as most of them could not recognize it. Restricted use and application was another sign of its less popularity in traditional medicinal system of Sundarban area. However, five of the respondent, all of them were illiterate, including kavirajes, fishermen and forest guard took the interviewers in areas from where they collected the plant, pointed out the plant, and mentioned their uses. They learned this knowledge from their forefathers. So it was difficult to gather much information in shortened period field works.

Kavirajes and folk medicine practitioners of our country have been using $B$. lacera and its relatives in their medicinal system for a long time (Islam et al., 2012). B. lacera grow in Sundarban area locally known as Bonpalang, Bontamak etc. It had strong pungent smell when squashed. Among the visited three sites, Dublar Char had the highest salinity (about 20 ppt). The salinity in Kalagachia and Kotka ranged between 13 and 14 ppt (Hossain, 2003). Among the five informants, two form Dublar Char, another two from Kalagachia and one from Kota were interviewed (Table 1).

Rahman (2013) reported the use of B. lacera as fuels and juice of the leaves as an anthelmintic, febrifuge, astringent, and diuretic in Rajshahi district of Bangladesh. He also mentioned use of the herb in bleeding piles. Mollik et al. (2010) reported the ethnomedicinal use of $B$. lacera for gastrointestinal disorder and as an insect repellent in Bagerhat Sadar and Rampal area of Bagerhat district of Bangladesh. 
Table 1. Ethnobotanical information on B. lacera at different sites of Sundarban mangrove forest

\begin{tabular}{|c|c|c|c|c|}
\hline Site & $\begin{array}{c}\text { GPS } \\
\text { coordinates and } \\
\text { forest type* }\end{array}$ & $\begin{array}{l}\text { Name and age of } \\
\text { the informant }\end{array}$ & Profession & Uses \\
\hline \multirow{3}{*}{$\begin{array}{l}\text { Dublar } \\
\text { char }\end{array}$} & \multirow{3}{*}{$\begin{array}{l}\mathrm{N} 21^{\circ} 43^{\prime} 47^{\prime \prime} \\
\mathrm{E} 89^{\circ} 36^{\prime} 15.2^{\prime \prime} \\
\text { (Gewa-Kewra } \\
\text { type forest) }\end{array}$} & Aziz (37) & $\begin{array}{l}\text { Local } \\
\text { practitioner }\end{array}$ & $\begin{array}{l}\text { 1. Warm leaf paste is applied } \\
\text { to lower abdomen as diuretic. } \\
\text { 2. Leaves juice (approx. } 1 \text { tea } \\
\text { spoonful) with honey orally } \\
\text { taken to treat most kinds of } \\
\text { colds. }\end{array}$ \\
\hline & & $\begin{array}{l}\text { Mrinmoy Nandi } \\
\text { (63) }\end{array}$ & Kaviraj & $\begin{array}{l}\text { 1. Root and stem decoction is } \\
\text { taken to treat blood dysentery. } \\
\text { 2. Leaf paste ( }\left(2^{1 / 2} \text { tea }\right. \\
\text { spoonful) with black pepper } \\
\text { powder ( } 1 \text { tea spoon) is } \\
\text { applied in dog bite. }\end{array}$ \\
\hline & & & & $\begin{array}{l}\text { 3. Leaf juice ( } 1 \text { cup) mixed } \\
\text { with a tea spoonful of mustard } \\
\text { seed is orally taken to relieve } \\
\text { piles. }\end{array}$ \\
\hline \multirow{3}{*}{ Kalagachia } & \multirow{3}{*}{$\begin{array}{l}\mathrm{N} 22^{\circ} 13.124^{\prime} \\
\mathrm{E} 89^{\circ} 14.329^{\prime} \\
\text { (Gewa-Goran- } \\
\text { Poshur type } \\
\text { forest) }\end{array}$} & Shafiuddin (51) & Fisherman & $\begin{array}{l}\text { 1. Leaf paste is applied on } \\
\text { forehead for the treatment of } \\
\text { fever and to the joints for } \\
\text { gout. }\end{array}$ \\
\hline & & & & $\begin{array}{l}\text { 2. Pellet of leaf and seed } \\
\text { powder is taken in } \\
\text { leucorrhoea. }\end{array}$ \\
\hline & & Malek (45) & $\begin{array}{l}\text { Forest } \\
\text { Guard }\end{array}$ & $\begin{array}{l}\text { Native people use the herb in } \\
\text { the treatment of bleeding } \\
\text { piles. }\end{array}$ \\
\hline Kotka & $\begin{array}{l}\mathrm{N} 21^{\circ} 51.263^{\prime \prime} \\
\text { E89 } 47.257^{\prime} \\
\text { (Sundari-Gewa- } \\
\text { Kewra type } \\
\text { forest) }\end{array}$ & Idris miah (39) & $\begin{array}{l}\text { Forest } \\
\text { Guard }\end{array}$ & $\begin{array}{l}\text { Warm decoction of the plant } \\
\text { is applied to hasten the } \\
\text { expulsion of placenta after } \\
\text { childbirth. }\end{array}$ \\
\hline
\end{tabular}

* Source: Hossain, 2003.

Kumar \& Bhagat (2012) reported that roots and leaves of B. lacera are used as antipyretic and root decoction of Blumea hieracifolia for gastric trouble in Nepal. Leaf juice used as an astringent, febrifuge, diuretic and anti-helminthic whilst leaf paste along with a pinch of common salt is applied externally to cure eczema and ring worm (Satapathy et al., 2012). 
Table 2. Antibacterial activities of different fractions of $\boldsymbol{B}$. lacera collected from JU campus and Sundarban mangrove forest

\begin{tabular}{|c|c|c|c|c|c|c|c|c|c|c|c|c|}
\hline Fractions & Sample & $\begin{array}{c}\text { Dose } \\
(\mu 1)\end{array}$ & $\begin{array}{c}\text { Bacillus } \\
\text { subtilis }\end{array}$ & $\begin{array}{c}\text { Bacillus } \\
\text { cereus }\end{array}$ & $\begin{array}{c}\text { Vibrio } \\
\text { cholerae }\end{array}$ & $\begin{array}{c}\text { Pseudom- } \\
\text { onas } \mathrm{sp} .\end{array}$ & $\begin{array}{c}\text { Serratia } \\
\text { sp. }\end{array}$ & $\begin{array}{c}\text { Erwinia } \\
\text { sp. }\end{array}$ & $\begin{array}{c}\text { Protius } \\
\text { mirabilis }\end{array}$ & $\begin{array}{l}\text { Shigella } \\
\text { flexneri }\end{array}$ & $\begin{array}{c}\text { Salmone- } \\
\text { lla } \mathrm{sp} .\end{array}$ & $\begin{array}{l}\text { Salmone- } \\
\text { lla typhi }\end{array}$ \\
\hline \multirow{6}{*}{$n$-hexane } & \multirow{3}{*}{$\mathrm{JU}$} & 40 & $8 a$ & $8 a$ & $8 a$ & $8 \mathrm{a}$ & $8 a$ & $8 \mathrm{a}$ & $8 a$ & $8 a$ & $8 a$ & $8 a$ \\
\hline & & 80 & $8 \mathrm{a}$ & $8 a$ & $8 \mathrm{a}$ & $8 \mathrm{a}$ & $8 a$ & $8 a$ & $8 \mathrm{a}$ & $8 a$ & $8 a$ & $8 a$ \\
\hline & & 120 & $8 \mathrm{a}$ & $8 \mathrm{a}$ & $8 a$ & $8 \mathrm{a}$ & $8 a$ & $8 a$ & $8 a$ & $8 \mathrm{a}$ & $8 a$ & $8 \mathrm{a}$ \\
\hline & \multirow{3}{*}{$\begin{array}{l}\text { Sundar- } \\
\text { ban }\end{array}$} & 40 & $8 \mathrm{a}$ & $8 \mathrm{a}$ & $8 \mathrm{a}$ & $8 \mathrm{a}$ & $8 a$ & $8 a$ & $8 a$ & $8 \mathrm{a}$ & $8 a$ & $8 a$ \\
\hline & & 80 & $8 a$ & $8 a$ & $8 a$ & $8 \mathrm{a}$ & $8 a$ & $8 a$ & $8 a$ & $8 a$ & $8 a$ & $8 a$ \\
\hline & & 120 & $8 \mathrm{a}$ & $8 \mathrm{a}$ & $8 \mathrm{a}$ & $8 \mathrm{a}$ & $8 a$ & $8 a$ & $8 a$ & $8 a$ & $8 a$ & $8 a$ \\
\hline \multirow{6}{*}{$\begin{array}{l}\text { Ethyl } \\
\text { acetate }\end{array}$} & \multirow{3}{*}{ JU } & 40 & $8 \mathrm{a}$ & $9.33 \mathrm{a}$ & $8 b$ & $8 \mathrm{a}$ & $8 a$ & $8 a$ & $8 a$ & $8 \mathrm{a}$ & $8 a$ & $8 a$ \\
\hline & & 80 & $8 \mathrm{a}$ & $11 \mathrm{a}$ & $9.17 \mathrm{~b}$ & $8 \mathrm{a}$ & $8 \mathrm{a}$ & $8 a$ & $8 a$ & $8 \mathrm{a}$ & $8 a$ & $8 a$ \\
\hline & & 120 & $8 \mathrm{a}$ & $14 \mathrm{a}$ & $10.33 b$ & $8 \mathrm{a}$ & $9.50 \mathrm{~b}$ & $8 a$ & $8 a$ & $8 a$ & $8 a$ & $8 a$ \\
\hline & \multirow{4}{*}{$\begin{array}{l}\text { Sundar- } \\
\text { ban }\end{array}$} & 40 & $8 a$ & $10.67 \mathrm{a}$ & $8 a$ & $8 \mathrm{a}$ & $8 a$ & $8 a$ & $8 a$ & $8 \mathrm{a}$ & $8 a$ & $8 \mathrm{a}$ \\
\hline & & 80 & $8 \mathrm{a}$ & $13.83 \mathrm{a}$ & $8 \mathrm{a}$ & $8 \mathrm{a}$ & $8 a$ & $8 a$ & $8 a$ & $8 \mathrm{a}$ & $8 a$ & $8 a$ \\
\hline & & 120 & $8 \mathrm{a}$ & $14.50 \mathrm{a}$ & $8 \mathrm{a}$ & $8 \mathrm{a}$ & $8 a$ & $8 a$ & $8 a$ & $8 a$ & $8 \mathrm{a}$ & $8 a$ \\
\hline \multirow{6}{*}{ Methanol } & & 40 & $8 \mathrm{a}$ & $8 \mathrm{a}$ & $8 a$ & $8 \mathrm{a}$ & $8 \mathrm{a}$ & $8 \mathrm{a}$ & $8 \mathrm{a}$ & $8 a$ & $8 \mathrm{a}$ & $8 a$ \\
\hline & \multirow[t]{2}{*}{ JU } & 80 & $8 a$ & $8 \mathrm{a}$ & $8 a$ & $8 \mathrm{a}$ & $8 \mathrm{a}$ & $8 a$ & $8 a$ & $8 \mathrm{a}$ & $8 a$ & $8 \mathrm{a}$ \\
\hline & & 120 & $8 \mathrm{a}$ & $8 \mathrm{a}$ & $8 \mathrm{a}$ & $8 \mathrm{a}$ & $8 \mathrm{a}$ & $8 \mathrm{a}$ & $8 \mathrm{a}$ & $8 \mathrm{a}$ & $8 a$ & $8 \mathrm{a}$ \\
\hline & \multirow{3}{*}{$\begin{array}{l}\text { Sundar- } \\
\text { ban }\end{array}$} & 40 & $8.83 \mathrm{cde}$ & $8 \mathrm{a}$ & $9.50 \mathrm{c}$ & $8 a$ & $12.50 \mathrm{a}$ & $8.50 \mathrm{de}$ & $11.33 b$ & $9 \mathrm{~cd}$ & $8 \mathrm{a}$ & $9.50 \mathrm{c}$ \\
\hline & & 80 & $9.33 \mathrm{~cd}$ & $8 \mathrm{a}$ & $10.17 \mathrm{c}$ & $8 \mathrm{a}$ & $13.17 \mathrm{a}$ & $8.83 \mathrm{de}$ & $12.17 \mathrm{~b}$ & $9.83 \mathrm{~cd}$ & $8 a$ & $10.33 \mathrm{c}$ \\
\hline & & 120 & $10.83 \mathrm{~b}$ & $10.17 \mathrm{~b}$ & $11.33 \mathrm{~b}$ & $10.33 b$ & $14 \mathrm{a}$ & $10.33 b$ & $13 \mathrm{a}$ & $11.17 \mathrm{~b}$ & $8 a$ & $10.67 \mathrm{~b}$ \\
\hline
\end{tabular}

NB: In a column means followed by common letters are not significantly different at $5 \%$ level by DMRT. *Disc diameter $=8 \mathrm{~mm}$

The use of plant extracts or phytochemicals with known antimicrobial properties can be of great significance for therapeutic treatments (Jaimini et al., 2011). Plants have been found in vitro to have antimicrobial property as they are rich in a wide variety of secondary metabolites, such as tannins, terpenoids, alkaloids and flavonoids (Cowan, 1999). In this study, the antibacterial property of methanolic extracts of the aerial parts have been tested against ten bacterial strains to evaluate the broad-spectrum antimicrobial properties of B. lacera (Table 2).

Two gram positive bacteria namely Bacillus subtilis and B. cereus and eight gram negative bacteria namely Vibrio cholerae, Pseudomonas sp., Serratia sp., Salmonella typhi, Salmonella sp., Proteus mirabilis, Erwinia sp., and Shigella flexneri were used in the present experiment. $n$-hexane fractions of JU and Sundarban samples showed no antibacterial activity whereas ethyl acetate fraction of both the samples showed inhibitory affect against all the tested bacteria under investigation (Fig. 1). Maximum zone of inhibition produced by ethyl acetate fraction was $14 \mathrm{~mm}$ for $120 \mu \mathrm{g} / \mathrm{ml}$ against Bacillus cereus followed by $13.83 \mathrm{~mm}$ for $80 \mu \mathrm{g} / \mathrm{ml}$ and $10.67 \mathrm{~mm}$ for $40 \mu \mathrm{g} / \mathrm{ml}$ respectively. Thus the finding from the present experiment suggest that the ethyl acetate fraction of $B$. lacera, irrespective of habitat choice was active against the gram positive bacteria Bacillus cereus following dose dependency (Fig. 2).

The methanol fraction of JU sample did not produce any inhibition zone whereas Sundarban sample showed broad spectrum inhibition against both gram positive and gram negative bacteria except Salmonella sp. The methanol fraction of Sundarban sample 
showed significant dose dependent increase in antibacterial activity against the gram negative bacteria namely, Serratia sp., Proteus mirabilis, Salmonella typhi and Vibrio cholerae. The highest inhibition zone of this fraction recorded as $14 \mathrm{~mm}$ and $13 \mathrm{~mm}$ against Serratia sp. and Proteus mirabilis, respectively whereas Bacillus cereus showed the lowest inhibition zone $(10.17 \mathrm{~mm})$ (Table 2). These observations were more likely to be the fact that an outer membrane in gram negative bacteria, which acts as a barrier to many environmental substances including antibiotic (Panda et al., 2012).

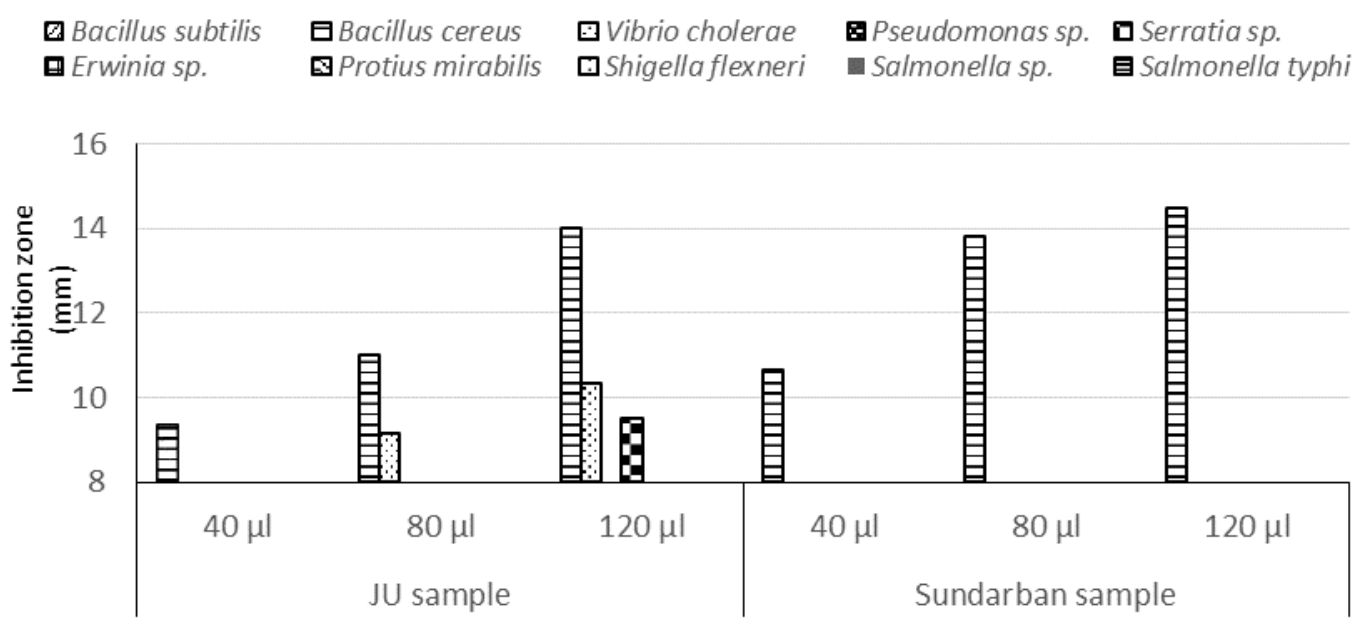

Fig. 1. Antibacterial activity of ethyl acetate fractions of $B$. lacera collected from JU campus and Sundarban mangrove forest

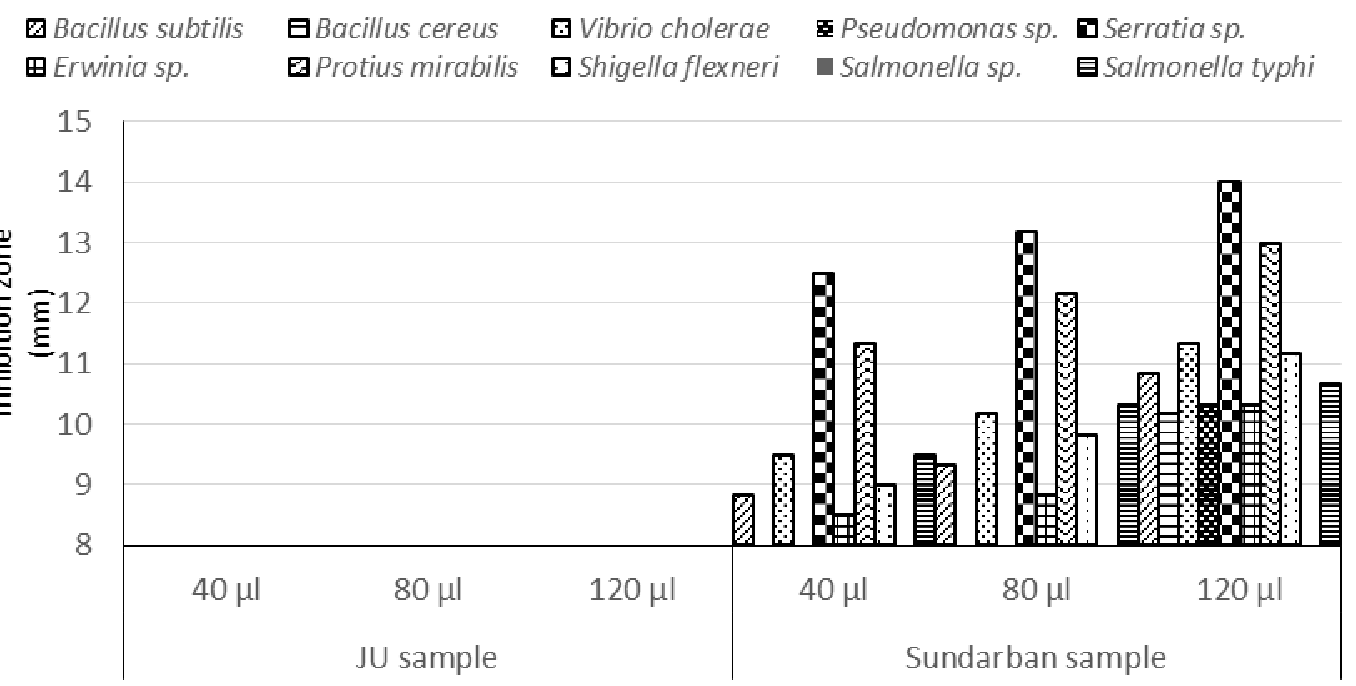

Fig. 2. Antibacterial activity of methanol fractions of B. lacera collected from JU campus and Sundarban mangrove forest 
A number of review and research article provide the information of the antibacterial activities in B. lacera and the members of Asteraceae family. Singh et al. (2010) reported that the methanol extract showed good inhibitory activity against Staphylococcus aureus, Bacillus subtilis, Serratia marcescens, Staphylococcus aureus and Candida albicans which corroborates with findings of Sundarbans sample of the present study. In contrast, Tiwari et al. (2012) reported $13 \mathrm{~mm}(100 \mu \mathrm{g} / \mathrm{ml})$ inhibition zone against Bacillus subtilis and Escherichia coli respectively with the chloroform fraction of B. lacera. However, Islam et al. (2008) reported that B. lacera showed most promising antibacterial properties indicating the potential for discovery of new antibacterial drugs. The present study suggests that the methanol fraction of the aerial parts of $B$. lacera collected from Sundarban could be relatively potential source of antibacterial agent than the other fractions. Thus further extensive work on B. lacera growing in Sundarban may lead to the isolation of interesting therapeutic compound and future work in this regard is needed.

Acknowledgement: The authors would like to express their gratitude to University Grants Commission (UGC) of Bangladesh for providing the research fund during 20112012 financial year.

\section{REFERENCES}

Akinpelu, D.A., Aiyegoro, A.O. and Okoh, A.I. 2009. Studies on the biocidal and cell membrane disruption potentials of stem bark extracts of Afzelia africana Smith. Biol Res. 42: 339349.

Cowan, M.M. 1999. Plant product as antimicrobial agents. Clin. Microbiol. Rev. 12: 564-582.

Gentry, A.H. 1993. Tropical forest biodiversity and the potential for new medicinal plants. In: Human Medicinal Agents from Plants. (Eds. by Kinghorn, A.D., Balandrin, M.F.), American Chemical Society, Washington, DC. pp.13-24.

Hossain, A.B.M.E. 2003. Final report on the undergrowth species of Sundarban mangrove ecosystem (Bangladesh). Sundarban biodiversity conservation project. pp. 10-11.

Islam, M. J., Barua, S., Das, S., Khan, M. S. and Ahmed, A. 2008. Antibacterial Activity of Some Indigenous Medicinal Plants. J .Soil .Nature. 2(3): 26-28.

Islam, M.T., Das, P.R., Kabir, M.H., Akter, S., Khatun, Z., Haque, M.M., Roney, M.S.I., Jahan, R. and Rahmatullah, M. 2012. Acanthaceae and Asteraceae family plants used by folk medicinal practitioners for treatment of malaria in Chittagong and Sylhet divisions of Bangladesh. American-Eurasian J. Sustainable Agric., 6(3): 146-152.

Jaimini, M.; Mahida, Y. and Mohan, J.S.S. 2011. Screening of Indian plant extracts for antibacterial activity. Pharma. Biol. 44(8): 627-631.

Jha, R.R. and Verma, S.K. 1996. Ethnobotony of Sauria Paharias of Santhal Pargana, Bihar: Indian Medicinal plants. Ethnobotany, 8: 31-35.

Joshi, M.C. 1980. Some folk medicine of Danga, Gujarat state. Bull Med. Ethnobot Res. 1: 8-24.

Kakrani, H.K.N. and Saluja, A.K. 1994. Traditional through herbs in Kutch district Gujarat state, India. Analgesic, anti-inflammatory, antirheumatic, antiarthritic plants, Fitoterapia, 65: 427-430.

Kumar, R. and Bhagat, N. 2012. Ethnomedicinal plants of district Kathua (J\&K). Int. J. Med. Arom. Plants. 2(4): 603-611.

Kupchan, S.M. and Tsou, G. 1973. Tumor inhibitors-A new antileukemic simaroubolide from Brucea antidysenterica. J. Org. Chem. 38: 178-179. 
Macilwain, C. 1998. Plants Used Against Cancer, Quarterman, Lawrence, Massachusetts. Ann. Clin. Psychiatry, 392: 535-540.

Martin, G.J. 1995. Ethnobotany: a 'People and Plants' Conservation Manual, Chapman and Hall, London, pp. 268.

Maundu, P. 1995. Methodology for collecting and sharing indigenous knowledge: a case study. Indigenous Knowledge and Development Monitor, 3: 3-5.

Mollik M.A.H., Hossan, M.S., Paul, A.K., Rahman, M.T., Jahan, R. and Rahmatullah, M. 2010. A comparative analysis of medicinal plants used by folk medicinal healers in three districts of Bangladesh and inquiry as to mode of selection of medicinal plants. Ethnobotany Res. Applications, 8:195-218.

Pal, R. 1972. Campesterol from Blumea lacera. Phytochemistry. 11: 18-55.

Panda, S.K., Pati, D., Mishra. S.K., Sahu, S., Tripathy, B. and Nayak, L. 2012. Phytochemical investigation \& antimicrobial activity of methanolic extract of Sonneratia apetala BuchHam. Areal parts. Int. J. Pharma. Biol. Arch. 3(1): 79-83.

Pandit, B.R., Kotiwar O.S., Oza, R.A. and Kumar, R.M. 1996. Ethnomedicinal plant lore from Gir forest Gujarat. Adv. Plant Sci. 9 (1): 81-84.

Rahman, A.H.M.M. 2013. An ethnobotanical investigation on Asteraceae family at Rajshahi, Bangladesh. J. Business Admin. Management Sci. Res. 2(5): 133-141.

Saad, S., Taher, M., Susanti, D., Qaralleh, H. and Awang, A.F.I.B. 2012. In vitro antimicrobial activity of mangrove plant Sonneratia alba. Asian Pac. J. Trop. Med. 1:427-429.

Satapathy, K.B., Binod, B.S. and Jena, G.S. 2012. Crop weeds diversity and their ethnomedicinal uses in the treatment of common ailments in Jaipur district of Odisha, India. Int. J. Med. Arom. Plants. 2(1): 80-90.

Singh, B., Singh, S., Singh, S., Ali, L. and Mahajan, R. 2010. Ethnobotanical significance and antimicrobial activity of Blumea lacera (Roxb.) D.C. Intl. J. Pharma. Biol. Arch., 1(3): $314-316$.

Singh, H. 1988. Ethnobotonical treatment of piles by Bhoxas of Utterpradesh. Ancient Sci Life. 8: 167-170.

Singh, V.K., Siddiqui, M.K. and Aminuddin. 2007. Folk medicinal plants used for the treatment of bronchial asthma in India. Proc. IS on Med. and Nutraceutical Plants. (Ed. by Yadav A.K.), Acta Hort. pp. 63-66.

Tiwari, P., Saluja, G., Pandey, A.S. and Sharma, N. 2012. Isolation and biological evaluation of some novel phytoconstituents from Blumea lacera (Burn F.) D.C. Int. J. Pharm. Pharm. Sci. 4(4):148-150.

Tomoko, N., Takashi, A., Hiromu, T., Yuka, I., Hiroko, M., Munekazu, I., Totshiyuki, T., Tetsuro, I., Fugio, A., Iriya, I., Tsutomu, N. and Kazuttito, W. 2002. Antibacterial activity of extracts prepared from tropical and sub-tropical plants on methicillin resistant Staphylococcus aureus. J. Health. Sci. 48: 273-289.

Uddin, S.J., Grice, I.D. and Tiralongo, E. 2011. Cytotoxic effects of Bangladeshi medicinal plant extracts. Evidence-Based Compl. Alter. Med. 2011:1-7.

Wagenen, B.C.V., Larsen, R., Cardellina, J.H., RanDazzo, D., Lidert, Z.C. and Swithenbank, C. 1993. Ulosantoin, a potent insecticide from the sponge Ulosa ruetzleri. J. Org. Chem. 58: 335-337. 